Abstracta Iranica Abstracta Iranica

Revue bibliographique pour le domaine irano-aryen

Volume 28 | 2007

Comptes rendus des publications de 2005

"No One Will Scratch my Back: Iranian Security
Perceptions in Historical Context ». Middle East

Journal, vol. 59, $\mathrm{n}^{\circ}$ 2, printemps 2005, pp. 209-229.

Anicée Van Engeland

(2) OpenEdition

Journals

Édition électronique

URL : http://journals.openedition.org/abstractairanica/19291

DOI : 10.4000/abstractairanica. 19291

ISSN : 1961-960X

Éditeur :

CNRS (UMR 7528 Mondes iraniens et indiens), Éditions de l'IFRI

Édition imprimée

Date de publication : 15 mai 2007

ISSN : 0240-8910

Référence électronique

Anicée Van Engeland, « « No One Will Scratch my Back: Iranian Security Perceptions in Historical

Context ». Middle East Journal, vol. 59, n² 2, printemps 2005, pp. 209-229. », Abstracta Iranica [En ligne],

Volume 28 | 2007, document 433, mis en ligne le 18 septembre 2007, consulté le 25 septembre 2020.

URL : http://journals.openedition.org/abstractairanica/19291 ; DOI : https://doi.org/10.4000/

abstractairanica.19291

Ce document a été généré automatiquement le 25 septembre 2020.

Tous droits réservés 


\section{« No One Will Scratch my Back: Iranian Security Perceptions in Historical Context ». Middle East Journal, vol. 59, $\mathrm{n}^{\circ} 2$, printemps 2005, pp. 209-229.}

\section{Anicée Van Engeland}

L'A. lie la perception qu'ont les Iraniens de la sécurité aux expériences de l'histoire. Il explique que les réalités géopolitiques et la psychologie nationale définissent ainsi la sécurité nationale. Cet article tente de définir cette psychologie nationale en matière de sécurité. Par exemple, l'acquisition de l'arme nucléaire est à la fois une réalité géopolitique et un objet de fierté nationaliste iranien. C'est pour cette raison que les Iraniens soutiennent en masse le projet nucléaire. Enfin il explique que la définition de la sécurité nationale est aussi due aux conséquences des interventions étrangères (notamment dans les pays voisins de l'Iran) et il suggère que les États-Unis prennent cela en compte dans leurs négociations diplomatiques.

\section{INDEX}

Thèmes : 13.1. Iran 
AUTEURS

ANICÉE VAN ENGELAND

Paris 